\title{
OPERÁRIAS DA COMPANHIA FIAÇÃO E TECIDOS PELOTENSE E SUAS TÁTICAS DE GÊNERO (1944-1954)
}

Eduarda Borges da Silva ${ }^{1}$

Artigo recebido em: 26/05/2018

Artigo aceito em: 02/07/2018

\section{RESUMO:}

Através dos processos da Justiça do Trabalho de Pelotas, salvaguardados no Núcleo de Documentação Histórica da Universidade Federal de Pelotas (UFPel), observou-se pleitos de operárias da Companhia Fiação e Tecidos Pelotense, entre 1944-1954. Esta fábrica atuou de 1908 a 1974, no bairro da Várzea, atual zona do Porto de Pelotas - RS e tinha a maioria de sua mão-de-obra composta por mulheres. A partir dos conceitos de ideologia da domesticidade e táticas de gênero buscou-se descrever e compreender os dissídios em que o dilema da dupla jornada da trabalhadora (divisão entre a fábrica e o lar), ocorreu e como estas mulheres operárias, mães, esposas, donas-de-casa apropriaram-se ou aceitaram a imagem de "mulheres sacrifícios". Foram buscadas, nas suas demandas e táticas, mulheres em ação.

\section{PALAVRAS-CHAVE:}

Operárias - Justiça do Trabalho - Táticas de gênero

\section{RESUMEN:}

A través de los procesos de la "Justiça do Trabalho de Pelotas", salvaguardados en el "Núcleo de Documentação Histórica" (UFPel), se observaron procesos de obreras de la “Companhia Fiação e Tecidos Pelotense”, entre 1944-1954. Esta fábrica actuó de 1908 a 1974, en el barrio de la "Várzea", actual zona del Puerto de Pelotas - RS y tenía la mayoría de su mano de obra compuesta por mujeres. A partir de los conceptos de ideología de la domesticidad y tácticas de género se buscó describir y comprender los procesos en que el dilema de la doble jornada de la trabajadora (división entre la fábrica y el hogar), ocurrió y

\footnotetext{
1 Mestra em História pela Universidade Federal de Pelotas e Doutoranda em História na Universidade Federal do Rio Grande do Sul. Membro do GT Estudos de Gênero ANPUH-RS e do Núcleo Interdisciplinar de Estudos sobre a Mulher e Gênero (NIEM) da UFRGS. Currículo Lattes: http://buscatextual.cnpq.br/buscatextual/visualizacv.do?id=K4400656Y9
} 
como estas mujeres obreras, madres, esposas, las amas de casa se aprópiáastrado em História da UFR la imagen de "mujeres sacrificios". Se buscó, en sus demandas y tácticas, mujeres en acción.

\title{
PALABRAS CLAVE:
}

Obreras - Justicia del Trabajo - Tácticas de Género

\section{INTRODUZINDO A TESSITURA}

\begin{abstract}
A voz pequenina da revolucionária surge nas faces vermelhas da agitação. [...] Tiram do nosso seio a última gota de leite que pertence a nossos filhinhos para viver no champanhe e no parasitismo! [...] Nós, à noite, nem força temos para acalentar nossas crianças que ficam sozinhas e largadas o dia inteiro ou fechadas em quartos imundos, sem ter quem olhe para elas. [...] Se nós não defendermos as nossas reivindicações, quem correrá em nosso auxílio? (GALVÃO, 2006, p. 87-88)
\end{abstract}

A Companhia Fiação e Tecidos Pelotense em 22 de abril de 1948 buscou a sede da Junta de Conciliação e Julgamento de Pelotas (JCJ), situada à época na Rua 15 de Novembro, $n^{\circ} 663$ para abrir um inquérito de apuração de falta grave a uma de suas operárias, Nair Pereira de Freitas.

A trabalhadora acusada de abandono de emprego ingressou na fábrica em janeiro de 1928, possuía, portanto, estabilidade, ou seja, tinha mais de dez anos na empresa. Isto indica, segundo a legislação vigente no período, que não poderia ser demitida sem justa causa.

O inquérito de Nair foi julgado procedente pela JCJ e ela teve sua despedida formalizada. Logo após, ingressou com uma reclamatória (junho de 1948) pleiteando salários atrasados e alegando que a partir de 19 de setembro de 1947 passou a faltar ao trabalho, pois estava com um filho adoentado, o qual veio a falecer. E, como a empresa requerida não possuía creche e devido a suas poucas condições - recebia Cr\$2,55 por hora, não podia contratar uma babá, com isso, precisou se afastar temporariamente do serviço para cuidar do filho. 


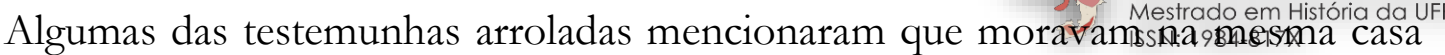
de cômodos que Nair, localizada na Rua Telles, $n^{\circ}$ 1. E, por conhecerem-na bem sabiam que este era o segundo filho da reclamante que falecia, que seu esposo também trabalhava e que ela não tinha com quem deixar os filhos durante sua jornada fabril.

Na leitura inicial do processo não se sabia que Nair em 19 de setembro de 1947, último dia que compareceu ao trabalho, estava em seu terceiro mês de gravidez. Talvez ela também não soubesse que suas faltas se prolongariam para além do cuidado com o filho adoentado, mas, também, com a fase final da gestação e com o puerpério.

Em 11 de abril de 1948 a operária perdeu outro filho e aos 23 dias do mesmo mês deu à luz, sendo este o seu quarto parto, um dia após a abertura do inquérito movido pela Companhia Fiação e Tecidos Pelotense (Processo 172/48).

Este processo faz parte do Acervo da Justiça do Trabalho da Comarca de Pelotas, que está salvaguardado desde 2005 pelo Núcleo de Documentação Histórica da Universidade Federal de Pelotas e passa por análises quanti-qualitativas, possibilitando que histórias como as de Nair ganhem notabilidade. Neste acervo, diferente da maioria dos documentos públicos oficiais, as histórias das mulheres podem ser percebidas em ação, pleiteando por direitos.

A primeira parte desse artigo se deterá a uma breve discussão sobre as mulheres trabalhadoras e a industrialização, ao conceito de ideologia da domesticidade e aos comentários do Juiz da Junta de Conciliação e Julgamento de Pelotas no período em análise, Mozart Russomano, sobre o capítulo da Consolidação das Leis do Trabalho (CLT) dedicado às mulheres.

Já a segunda parte compreenderá como imagens de gênero foram utilizadas enquanto formas de poder nos processos trabalhistas da Comarca de Pelotas, tratando de questões metodológicas da fonte. Para tanto, são analisados quatro processos que possibilitam o debate sobre a dupla jornada da mulher trabalhadora.

\section{AS TRABALHADORAS E A IDEOLOGIA DA DOMESTICIDADE}


A mulher sempre trabalhou. Todavia, tornou-se uma figura isspictado en História da UFR visível” com a Revolução Industrial (SCOTT, 1992a). Dizia-se que a mulher antes de trabalhar fora do lar cumpria com êxito atividade produtiva e criação dos filhos, trabalho e domesticidade, mas que depois esta se tornou uma combinação difícil, se não impossível.

Joan Scott (1992a) e Michelle Perrot (1988) chamaram atenção para alguns equívocos sobre a mulher trabalhadora e os primórdios da industrialização: muitas etapas da produção industrial eram desenvolvidas em casa, como a costura e a montagem, seja de sapatos ou vestuário; a industrialização antes de querer destruir ou desmoralizar a família pretendeu utilizar-se desta organização social para fins econômicos; o trabalho doméstico se desvalorizou depois que a produção de alimentos e roupas passou a ser também fabricada por indústrias; as mulheres trabalhavam regularmente fora de casa, antes da industrialização, como vendedoras ambulantes, lavadeiras e amas-de-leite; sendo que esta transferência não se deu do trabalho no domicílio para a fábrica, mas de um local de trabalho para outro. Afirmou Scott (1992a, p. 452) que “[...] não há, portanto, fortes razões para argumentar que a industrialização causou uma separação entre casa e trabalho, forçando a mulher a escolher entre domesticidade e trabalho remunerado".

Beatriz Loner (2001), referindo-se a Pelotas e Rio Grande na década de 1920, apontou que:

[...] embora cerca de um terço dos operários nas duas cidades, fossem mulheres, atuando como mão de obra na indústria, especialmente nas tecelagens, indústria de vestuário e toucador, elas eram presenças silenciosas, não tendo expressão mesmo nas entidades de trabalhadores (LONER, 2001, p. 67).

Nesta década, apesar das operárias de Pelotas ser "presenças silenciosas", ou melhor, silenciadas, as lutas feministas no Brasil começaram a ganhar alguns aparatos legais, como por exemplo, a primeira normatização ao trabalho das gestantes, através do Decreto no 16.300 de 1923, do Departamento Nacional de Saúde Pública, o qual assegurou o direito ao descanso, trinta dias antes do parto e trinta dias no puerpério, por meio do artigo 345 e o direito das empregadas ou operárias amamentarem e de disporem de um local para tanto, através dos artigos 348 e 350, respectivamente. 


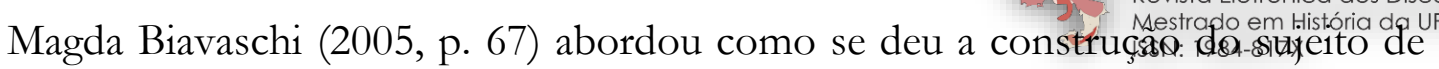
direitos trabalhista. Os/as trabalhadores/as, através do trabalho fabril remunerado, da legislação social, da criação de espaços tutelares, como a Justiça do Trabalho, foram se apropriando da sua condição e passaram a lutar por seus direitos. Esta autora percebeu o Direito do Trabalho, em seu princípio, como um espaço de proteção ao trabalhador, imposto no sentido de "corrigir desigualdades".

Buscando as mulheres na tese de Biavaschi compreende-se a conquista deste status de sujeito de direitos pelas trabalhadoras brasileiras como uma soma de fatores, não apenas no campo do trabalho. Neste âmbito a apropriação dos direitos se deu pós 1932 e não a todas as mulheres, mas primeiramente às com trabalhos públicos e remunerados, sendo que muitas, ainda na atualidade, têm a sua condição de trabalhadora desregulamentada ou em debate, como as mulheres rurais e as empregadas domésticas.

Além disso, em 1932 no campo político-social há outra conquista: o sufrágio. (KARAWEJCZYK, 2010). Também em 1932 foi criada a Carteira Profissional aos trabalhadores e trabalhadoras maiores de 16 anos da indústria e do comércio. Este documento era o marco identificador do/a operário/a ou comerciário/a, como pertencente à classe trabalhadora e também era um pré-requisito para que se buscasse o auxílio judiciário trabalhista (BIAVASCHI, 2005).

No mesmo ano as Juntas de Conciliação e Julgamento do Ministério do Trabalho foram instituídas no Brasil para mediar conflitos trabalhistas individuais. Já a criação da Justiça do Trabalho constou na Constituição de 1934, entretanto, só começou a funcionar em 1941, possuindo poder de execução, diferentemente da Junta (SPERANZA, 2012).

Todavia, na Europa a partir de fins do século XVIII e no Brasil pós 1930 ser mãe, mais do que nunca, tornou-se a principal função da mulher. Estabeleciam-se fronteiras rígidas entre a esfera pública, definida como essencialmente masculina, e a privada, vista como lugar natural da esposa-mãe-dona de casa e de seus filhos (RAGO, 1997).

Scott (1992a) definiu esta divisão naturalizada como ideologia da domesticidade. Este conceito irá permear a análise dos dissídios trabalhistas das operárias da Fiação e Tecidos Pelotense. 
A história da separação entre o lar e o trabalho seleciona e organiza a informação de modo a obter um certo efeito, um efeito que sublinha vincadamente diferenças biológicas e funcionais entre homens e mulheres, legitimando e institucionalizando assim essas diferenças como base para a organização social. Esta interpretação da história do trabalho feminino alimentou e contribuiu para a opinião médica, científica, política e moral a que se tem chamado, com variantes, "ideologia da domesticidade" [...] (SCOTT, 1992a, p. 445).

Esta ideologia da domesticidade imposta às mulheres trabalhadoras fora sustentada por vários pilares sociais: médicos e higienistas, preocupados com a capacidade de gestar da mulher e a saúde das crianças, ou seja, com o aumento da força produtiva, queriam a permanência daquela no lar em tempo integral (RAGO, 1997); maridos e pais tentavam impedir o trabalho noturno e fabril, com medo da "desonra", pois a fábrica era tida como um local promíscuo; já os industriários tinham uma posição ambígua: queriam manter a mão-de-obra feminina, porque estas percebiam salários inferiores, visto que este era tido como complementar ao do homem e eram consideradas mais submissas e menos engajadas politicamente em relação aos operários homens, porém, não entendiam a condição da gestante e os seus direitos legais.

E, o Estado a partir das leis intensificou a segregação entre os/as trabalhadores/as. Definiu a reprodução como papel primário da mulher e a atividade produtiva como secundária (SCOTT, 1992a), legitimando as tarefas do lar e a educação dos filhos como responsabilidades femininas.

Deste modo, a Consolidação das Leis do Trabalho (CLT) de 1943 dedicou um capítulo inteiro às mulheres, intitulado "Da proteção do trabalho da mulher". Este dispõe sobre: duração e condições de trabalho, trabalho noturno, períodos de descanso, métodos e locais de trabalho, proteção à maternidade e penalidades.

Mozart Victor Russomano, Juiz do Trabalho e Presidente da Junta de Conciliação e Julgamento da Comarca de Pelotas, no período em estudo escreveu o livro "Comentários à CLT", do qual aqui se utiliza a $5^{\mathrm{a}}$ edição, de 1960. Neste Russomano defendeu e justificou a necessidade de leis trabalhistas específicas às mulheres:

A debilidade orgânica que a marca, a natureza dos órgãos que a situam em seu sexo, as tradições seculares, os encargos domésticos, sua sensibilidade nervosa, seu feitio temperamental os deveres de família sobrecarregam a mulher- 
empregada, que é a mãe das gerações do futuro. É por isso Mestrado om História da UFR sociedade que ela esteja higiênica e espiritualmente defendida. Aí está todo o fundamento social das regras que a protegem [...] (RUSSOMANO, 1960, p. 558$559)$.

Sobre a proibição do trabalho noturno às mulheres, art. 379, compreendido entre as vinte e duas e às cinco horas do dia seguinte, exceto as maiores de 18 anos, empregadas em telefonias, radiotelefonias, radiotelegrafias, enfermeiras, em casas de diversões, hotéis, restaurantes e postos de direção, Russomano (1960, p. 560-561) defendeu que “[...] há tarefas que exigem o trabalho noturno. E muitas delas são confiadas, necessariamente as mulheres.” E, em relação à idade afirmou que aos 18 anos a trabalhadora poderá “[...] resistir aos encargos do trabalho noturno e aos malefícios, que, muitas vezes, daí decorre para a sua moralidade".

Quanto à proibição do trabalho da mulher em alguns locais, art. 387, como em minerações, Russomano (1960, p. 564) a justificou apontando a "reconhecida debilidade orgânica" da mulher. E, defendendo a importância do auxílio maternidade colocou este como um "patrimônio" à trabalhadora. E, alertou que "[...] quando contrata, a mulher, o patrão, presuntivamente, conhece as consequências que daí lhe advirão” (RUSSOMANO, 1960 , p. 570).

Observando o art. 397 Russomano (1960, p. 582) colocou que “[...] um dos grandes problemas que afligem as empregadas é o cuidado dos filhos durante as horas de trabalho". Ele percebia a criação de creches como solução às mães-trabalhadoras e denunciou que a lei facultava a criação de creches por parte dos empregadores, dependendo da "boa vontade" destes.

Percebe-se que o Juiz da Junta de Conciliação e Julgamento de Pelotas Mozart Russomano defendia a existência de uma legislação específica às trabalhadoras e o amparo destas, como o auxílio maternidade e a criação de creches. Entretanto, imerso nos "valores" e julgamentos morais de sua época, compreendia a mulher como mais frágil em relação ao homem, o trabalho noturno como um perigo à moralidade daquela e a contratação das mulheres como um problema aos patrões, pois estas poderiam engravidar e ausentar-se em função de suas atribuições reprodutivas. Em suma, o jurista que sentenciava as causas 
pesquisadas sobre as operárias da Companhia Fiação e Tecidos Pelotense Mestrado partilhava da ideologia da domesticidade.

Cristiane Lopes (2006) explica que normas como a proibição do trabalho noturno eram consideradas protetivas. Todavia, pretendiam recordar o lugar da mulher na sociedade de então (em casa, cuidando da família), porque o trabalho do homem também era explorado e providências semelhantes não foram tomadas. O que efetivamente buscouse proteger, na sua visão, foi a estrutura da família patriarcal.

Ainda em relação à restrição, mascarada como protetora, havia uma preocupação em delimitar o que era "trabalho de mulher" e o que não: “Tarefas que requeriam dedos delicados e ágeis, paciência e perseverança eram consideradas femininas, enquanto força muscular, velocidade e habilidade significavam masculinidade" (SCOTT, 1992a, p. 460). Apoiando-se num discurso da vulnerabilidade feminina, a atuação profissional das mulheres se tornou restrita. Assim, o ramo têxtil, em função do trabalho manual nos teares, tornou-se o grande setor de emprego das mulheres nas indústrias. Perrot (2008) justificou porque este era um trabalho temporário:

[...] as operárias não passam a vida toda na fábrica; são admitidas muito jovens, desde os 12 ou 13 anos, permanecem no trabalho até o casamento ou até o nascimento do primeiro filho, voltando a trabalhar mais tarde, quando os filhos estão criados, e, se necessário, com eles. É, pois, um trabalho cíclico, sem perspectiva de carreira (PERROT, 2008, p. 119).

Contudo muitas mulheres permaneceram ocupando postos de trabalho no âmbito público e tornando-se visíveis. Esta visibilidade do trabalho da mulher para Perrot (2008) originou-se no trabalho assalariado, sobretudo nos baixos salários, que as levaram a "perturbar" a disciplina e a ordem fabril. Já para Scott (1992a), esta visibilidade não trouxe à luz, a condição de explorada ou as experiências da mulher trabalhadora, mas tornou-se perceptível enquanto uma patologia social, na qual o esforço físico comprometia a capacidade reprodutora da trabalhadora e sua ausência do lar prejudicava a disciplina das suas casas.

Margareth Rago (1985) sustentou que essa imagem da mãe "inteira sacrifício" implicou numa completa desvalorização profissional, política e intelectual da mulher, 
porque parte do pressuposto de que esta deve primar pela maternidadé e Mestrado em História da urRN se através dos feitos dos seus filhos e marido, sendo incapaz de fazer algo por si. Segundo a autora, este modelo de mãe determinou, muitas vezes, as opções e condutas das mulheres.

Na sociedade brasileira o cuidado com a família e com o lar não é percebido como forma de trabalho. O trabalho reprodutivo (criação e cuidado dos filhos) é realizado ainda na atualidade, majoritariamente por mulheres e sem remuneração e reconhecimento social, embora seja um trabalho essencial para a reprodução da sociedade.

\begin{abstract}
Desde os primórdios, a luta pela própria sobrevivência ou a dos seus foi a marca de nossas ancestrais. A dupla jornada de trabalho existiu para maior parte delas. O trabalho no campo ou na cidade, em casa ou nas ruas, era acrescido de muitas outras tarefas, fundamentais para a estabilidade da família. Depois de um dia extenuante de trabalho fora, havia ainda o que fazer (DEL PRIORE, 2008, p. 96).
\end{abstract}

A partir dos processos das operárias da Cia. Fiação e Tecidos Pelotense (ESSINGER, 2009), se buscará compreender como se desenrolaram os pleitos em que a dupla jornada da mulher trabalhadora (trabalho produtivo + trabalho reprodutivo) tornouse visível em um âmbito que só o trabalho formal, oficial, público possui o reconhecimento como tal, a Justiça do Trabalho.

\title{
2. IMAGENS E TÁTICAS DE GÊNERO
}

De acordo com Margareth Rago (1997, p. 579), a documentação existente sobre o universo fabril foi quase majoritariamente produzida por autoridades públicas, ou seja, por aqueles que na maioria dos casos ocupavam o espaço público, sabiam ler e escrever: os homens. Isso significa que ao invés de se trabalhar com fontes produzidas pelas mulheres, com as quais elas pudessem se descrever, se identificar e se projetar para a posteridade, se lida com a construção masculina da identidade das mulheres trabalhadoras. "Sem rosto, sem corpo, a operária foi transformada numa figura passiva, sem expressão política [...]”.

Entretanto, a autora alertou que, na maior parte das vezes, essa expressão política e resistência feminina foram expressas de maneira espontânea e não-organizada, sendo invisíveis, portanto, para a lógica masculina da ação política. Rago (1985) atenta para a necessidade de apreender as diversas formas que essas expressões políticas assumiram. 


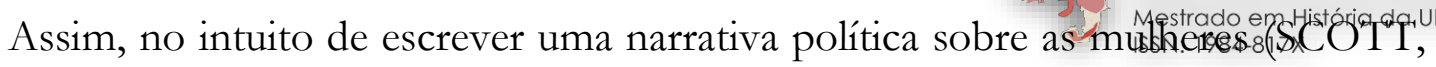
1992b) se buscou compreender como imagens de gênero foram utilizadas enquanto formas de poder nos processos trabalhistas da Comarca de Pelotas. O gênero nas ciências sociais é entendido, pela maioria dos pesquisadores, embora existam muitas divergências, como uma categoria de análise (SCOTT, 1995; SOIHET \& PEDRO, 2007), que compreende as atribuições de papéis aos homens e as mulheres como uma construção histórica, cultural e social, muitas vezes, imposta e reproduzida ou apropriada e tem por objetivo perceber as relações de poder entre os sexos. Nesta pesquisa, por exemplo, se escreve uma história sobre mulheres, mas seria impossível pensá-las de forma isolada, pois os processos judiciais foram datilografados por um homem, os advogados que as defenderam ou acusaram eram homens, bem como os que as julgaram.

Clarice Speranza (2012) comentou sobre algumas possibilidades desta fonte e suas "armadilhas":

[...] Os processos trabalhistas nos dão acesso mais facilitado às falas e às trajetórias dos trabalhadores "comuns", deixando entrever valores, contradições, resistências e adesões. Evidentemente que tais falas são mediadas pelo aparato judicial e, além disso, não estão lá inocentemente. Por mais humilde e "comum" que seja um operário, ele dificilmente entra num tribunal sem ter noção de que o que disser pode influenciar diretamente sua vida num futuro próximo. Portanto, é preciso saber olhar estas "armadilhas" e até tirar proveito delas [...] (SPERANZA, 2012, p. 33).

Para a análise dos pleitos judiciais trabalhistas das operárias da Companhia Fiação e Tecidos Pelotense entre 1944 e 1954, foram localizados doze processos que se reportam a dupla jornada, entretanto, cinco serão trabalhados nesta pesquisa.

Será dada atenção às "versões" e aos "significados", conforme apontou Sidney Chalhoub (2001), autor do livro "Lar, Trabalho e Botequim: o cotidiano dos trabalhadores no Rio de Janeiro da belle époque", no qual trabalhou com processos-crime:

[...] é na análise de cada versão no contexto de cada processo, e na observação da repetição das relações entre as versões em diversos processos, que podemos desvendar significados e penetrar nas lutas e contradições sociais que se expressam e, na verdade, produzem-se nessas versões ou leituras (CHALHOUB, 2001, p. 40-41). 
Outra importante percepção para a análise das contendas judiciasiastrago om História da UFRN de Ângela de Castro Gomes. Segundo ela a partir de 1980 houve uma mudança analítica acerca da relação entre dominantes e dominados, através da qual modelos que pensavam o trabalhador como ingênuo, submisso e conformado passaram a ser abandonados.

[...] [Esta revisão historiográfica] significa defender teoricamente que, entre seres humanos, não há controles absolutos e "coisificação" de pessoas, e que, nas relações de dominação, os dominantes não "anulam" os dominados, ainda que haja extremo desequilíbrio de forças entre os dois lados. Do ponto de vista empírico, portanto, a assertiva traz para a cena histórica, além de um sem número de ideias e ações dos dominantes, outro sem número de ideias e ações dos dominados, até então sequer imaginadas como possíveis (GOMES, 2004, p. 34).

Gomes (2004, p. 162) sustentou que embora a relação de dominação entre patrão e trabalhador seja desigual e hierárquica há momentos de "negociação", oriundos de "convergências de interesses", podendo até haver um "pacto político" entre dominados e dominantes. "O poder, nessa perspectiva teórica, não é um monopólio do dominante, existindo também no espaço dos dominados, o que não elimina a situação de desigualdade (muitas vezes radical) entre eles"

E, Mary Del Priore (2008, p. 84) alertou que escrever uma história das mulheres julgando suas ações enquanto erros ou acertos e olhá-las como heroínas ou mártires seria de um terrível anacronismo. "O que importa são desvendar as tensões, contradições e negociações que se estabeleceram, em diferentes épocas, entre elas e seu tempo; entre elas e a sociedade na qual estavam inseridas".

Inicialmente os processos em que a licença maternidade era pleiteada eram considerados pertencentes a esta discussão da dupla jornada. Entretanto, ao estudá-los com mais afinco, percebeu-se que as operárias que demandavam licença maternidade na Companhia Fiação e Tecidos Pelotense entre 1944-1954 o faziam quando já haviam retornado da licença. Assim, estavam demandando, em realidade, os salários que deveriam ter percebido no período de afastamento e não uma jornada mais flexível ou justificando ausências, em decorrência da gravidez e da maternidade, embora, certamente ao chegarem a suas casas, vindas do "trabalho produtivo", da jornada fabril, tivessem uma longa jornada de cuidar, limpar, amamentar, cozinhar, no "trabalho reprodutivo". 
Também, o direito a dois períodos de amamentação de trintá Mastrado em Hiśóría da UFR jornada, já era assegurado por lei e caso a empresa não possuísse local para tanto a operária teria de se deslocar ao seu lar para amamentar. Entretanto, nenhum dissídio relacionado à amamentação na fábrica e no período em questão foi encontrado.

Ainda, alguns processos em que as operárias estavam cuidando de parentes (avó, madrinha, marido) foram localizados, porém, uns não possuíam uma argumentação consistente acerca da dupla jornada e em outros o debate girava em torno de um tema diferente deste. Assim, serão elucidadas quatro contendas que possuem um enredo incitante ao debate sobre a dupla jornada da mulher trabalhadora, além do processo de Nair Pereira, abordado na introdução deste artigo e na conclusão do mesmo.

A Companhia Fiação e Tecidos Pelotense entrou com um pedido judicial de abertura de inquérito contra a sua trabalhadora Hilda Lopes, brasileira, solteira², fiandeira, em junho de 1948, acusando-a de abandono de emprego. A operária que trabalhava nesta empresa desde 1936 não compareceu à audiência e a Junta de Conciliação e Julgamento de Pelotas julgou-a "revel e confessa" dando ganho de causa à Companhia e permitindo a despedida da operária. Hilda recorreu da decisão proferida justificando não ter podido comparecer por ter uma filha doente há quase três meses, anexando o atestado médico aos autos.

O advogado da operária, Antônio Ferreira Martins, pediu que a sentença fosse reformada e amparando-se na ideologia da domesticidade (SCOTT, 1992a), apresentou sua cliente como uma "mãe-sacrifício":

Pode a recorrida alegar que doença de filho não excusa, não justifica. Mas, a verdade é que uma mãe pode ir doente, quase morrendo, trabalhar na fábrica, o que ela não fará se o doente for um filho. Esta, a realidade que a lei não pode contrariar e que se a lei contrariar, cabe aos tribunais interpretá-la de modo tal que não seja a lei uma iniquidade capaz de atentar contra os sentimentos mais sagrados da mulher! (Processo 200/48, fl. 8)

A reclamada, tentando manter a decisão proferida, sustentou-se numa citação de Dorval Lacerda sobre falta grave, na qual consta que se tratando de doença de familiar ou

\footnotetext{
2 Os processos informavam apenas nome, nacionalidade, estado civil e ocupação na fábrica, não sendo possível, portanto, identificar a cor/etnia das trabalhadoras.
} 
dependente o prazo de ausência é no máximo trinta dias, porque a molés tiaestrado em Histónia da uFPN é diferente da moléstia do trabalhador, que o impossibilita de trabalhar. Ultrapassando o prazo era configurada falta grave, abandono de emprego (Processo 200/48).

Antônio Martins, após recorrer ao Tribunal Regional e ter o recurso negado, protocolou pedido ao Tribunal Superior do Trabalho alegando que a operária não teve intenção de faltar, o que seria necessário para caracterizar abandono de emprego. Ainda, naturalizou o cuidado com os filhos como responsabilidade da mulher e defendeu que sempre que o dilema da dupla jornada se apresentar (deveres do lar e do trabalho) os tribunais e os patrões deveriam compreender que as obrigações da mãe estão acima das da operária.

\begin{abstract}
A reclamante colocou suas obrigações de mãe acima das suas obrigações de operária. Nem podia deixar de ser assim. Os patrões - quando não perdem sua qualidade de homens - devem admitir que tal aconteça, principalmente quando esses fatos são fatos comuns, [...] especialmente quando, como no caso, a maioria da fábrica é composta de mulheres. Entender o contrário não importa apenas em desconhecer a definição legal de falta grave, mas ainda em pretender que sejam violados direitos e obrigações inerentes à própria natureza humana (Processo 200/48, fl. 38).
\end{abstract}

Em abril de 1952 os juízes do TST decidiram unanimemente não prover o recurso por considerá-lo uma subversão às ordens das relações empregatícias, na qual “[...] o empregador passaria a ser subordinado aos interesses do obreiro" (Processo 200/48, fl. $54)$.

A operária Branca Pradier Oliveira, brasileira, casada, tecelã, trabalhou mais de doze anos (entre vários períodos) na Companhia Fiação e Tecidos Pelotense, quando em 1944 buscou a Junta de Conciliação e Julgamento de Pelotas para pleitear sua reintegração à fábrica (Processo 96/44).

Alegou que pediu uma licença para cuidar de seu marido João Oliveira que estava doente em Uruguaiana, onde foi trabalhar na Ponte Internacional Uruguaiana-Paso de Los Libres, e a empresa lhe disse que as licenças estavam terminadas. A demandante procurou o presidente do seu sindicato Nelson Neves Siqueira, o qual buscou a direção da fábrica a fim de tomar esclarecimentos. 


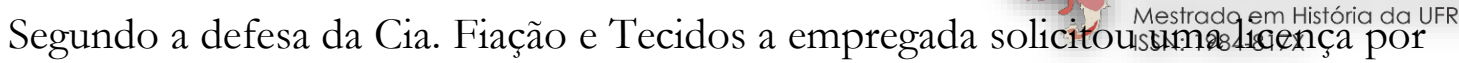
tempo indeterminado para seguir junto de seu esposo. Afirmaram que Branca reclamava que a despesa do casal era excessiva com a manutenção de duas casas. A empresa afirmou ter lhe oferecido trinta dias de licença, mas que a reclamante não aceitou e depois se apresentou pedindo trabalho porque seu esposo estava voltando para Pelotas e ela precisava trabalhar já que ele estava desempregado.

Foram chamadas as testemunhas Nelson Neves Siqueira, presidente do sindicato da reclamante (não mencionado) e Antônio Pacheco, contra-mestre da reclamada. Nelson afirmou que era acordo entre a empresa e o sindicato que qualquer demissão fosse feita por escrito e com assistência do sindicato, o que não ocorreu; que leu uma carta de um filho da reclamante na qual constava que o esposo desta estava doente, havendo ela solicitado licença por este motivo. Já Antônio afirmou que a reclamante demitiu-se da empresa por querer ir morar com seu esposo em Uruguaiana, porque as despesas com o casal separado eram excessivas.

Resolveu a JCJ de Pelotas por unanimidade de votos julgar procedente em parte a reclamatória, condenando a fábrica a pagar a operária a importância de CR $\$ 1.500,00$ relativos à indenização por demissão injusta e CR \$300,00 a título de aviso prévio, mais o custo processual no valor de CR\$134,00.

A Companhia recorreu ao Tribunal Regional e os juízes deste analisando o caso argumentaram:

\footnotetext{
A situação da reclamante é por demais clara e digna e perfeitamente explicável no presente caso. De um lado, nitidamente surge e nos antolha a empregada exata e cumpridora de seus deveres; por outro lado, se nos depara a esposa aflita face à notícia de doente estar em Uruguaiana o homem a quem ligara o seu destino. Premida, assim, por essas circunstâncias, a recorrida tudo fez para resolver e harmonizar a dura contingência de sua vida atribulada. Uma hora dramática a marcar e definir e exigir uma atitude que envolvesse e acobertasse os sagrados interesses da recorrida: atender seu esposo acamado e, simultaneamente, conservar o honrado auxílio com que equilibrando vinha as finanças domésticas. Nada mais justo, nada mais elevado que bem revela e esmalta uma grandeza d'alma aos maiores sacrifícios disposta (Processo $96 / 44$, fl. 54).
} 
Fica nítida a forma que a condição da dupla jornada foi apropria sestradi: C9aceritta como ideologia da domesticidade (SCOTT, 1992a). Desta vez, configurando a imagem da operária não como "mãe-sacrifício" do dissídio anterior, mas como "boa esposa”, aquela que falta ao trabalho para cuidar do marido e doa seu salário para complementar o dele. Tidas como "mulheres-sacrifício" estas operárias foram também vistas como "abnegadas colaboradoras". Prosseguiram os juízes do TRT da $4^{a}$ região:

Dir-se-á, talvez, a pureza de um sentimento que, na ara de uma sublime renúncia, tudo oferece em benefício de seu próprio lar. Nada mais humano e louvável, por certo. E tal costume, tal hábito da mulher altivamente ter como obrigação ajudar a enfrentar os encargos de família já se incorporou em definitivo ao nosso ambiente social. Sim, toda a sociedade, hoje em dia, civilizadamente americanizada, bate às palmas a mulher que trabalha e produz e, ombro a ombro, com o sexo forte vem conquistar o ganha-pão. E a tão magnífico movimento de opinião a nossa Legislação Social despertou também e reservou com carinho, destacadamente, um tratamento adequado e específico a tais abnegadas colaboradoras. Daí o assunto que os autos ventilam exigir do julgador, paritário ou técnico, um exame pelo duplo aspecto: humano e legal (Processo 96/44, fl. 54).

Os Juízes do Tribunal Regional do Trabalho da $4^{\mathrm{a}}$ região alegaram estar embasados nos fatos de que "a recorrida [Branca] sempre procurou manter e conservar o seu contrato de trabalho" e tinha a seu favor "uns quantos anos de casa". Por unanimidade de votos negaram provimento de recurso à Companhia Fiação e Tecidos Pelotense, confirmando a decisão anterior. No entanto, apesar de defenderem que seu julgamento deveria ser "humano e legal" estavam envoltos nesta ideologia da domesticidade da mulher (Processo $96 / 44$, fl. 54).

Sara Gronês, casada, Rita Jesus Pereira, solteira e Carmem Alberto, “desquitada”, todas brasileiras, foram suspensas sem justa causa em 14 de setembro de 1951. A primeira trabalhava na Companhia Fiação e Tecidos Pelotense desde 1936, a segunda a catorze anos e a terceira a nove anos. Em face da suspensão pleitearam a revogação da mesma, pois o aumento salarial era vinculado à assiduidade, o pagamento do dia de trabalho e de mais um domingo e um feriado, pois percebiam por dia.

Aos dez dias do mês de julho do ano de mil novecentos e um, às 14 horas, na sede da Junta de Conciliação e Julgamento, situada à Rua 15 de Novembro, 704, em Pelotas, foi aberta a audiência. Estavam presentes o Sr. Juiz-Presidente, Dr. Mozart Victor Russomano, 


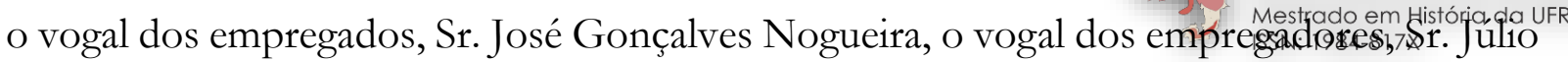

Real, a reclamante Carmen Alberto por si e em representação de suas companheiras de reclamatória e acompanhada de seu procurador, Antônio Ferreira Martins e a reclamada Cia. Fiação e Tecidos Pelotense representada pelo Sr. Aldo Sedrez e acompanhada de seu procurador, Dr. Alcides de Mendonça Lima (Processo 337-339/51).

Carmen informou que não estava autorizada a representar as demais reclamantes, assim o Presidente arquivou o pedido inicial das mesmas. Na sequência foi apresentada a defesa prévia:

[...] a reclamante [Carmen] e mais suas companheiras de processo, bem como outras três operárias, foram suspensas apenas por um dia útil, em virtude de terem deixado o serviço alguns minutos antes da hora da largada. Assim fazendo infringiram o regulamento da fábrica. A reclamada [Cia.] tem interesse em manter a disciplina do estabelecimento com todo o rigor, pois ultimamente lá se tem criado um clima de agitação (Processo 337-339/51, fl. 4).

A audiência foi logo suspensa pela ausência de testemunhas das partes. Marcada nova audiência para o dia 20 de julho de 1951, compareceram as reclamantes Sara Gronês, Rita de Jesus Pereira e Carmen Alberto acompanhadas do advogado Antônio Martins. A Companhia foi representada pelo Sr. Aldo Sedrez e pelo advogado Alcides de Mendonça Lima.

O procurador das demandantes apresentou suas razões finais, apropriando-se da condição da dupla jornada enquanto ideologia da domesticidade (SCOTT, 1992a). Afinal, as “ocupações caseiras e domésticas” pertenciam às donas-de-casa e não aos donos.

[...] a reclamação é procedente. As reclamantes foram suspensas, porque, juntamente com outras operárias, dois minutos antes da hora da largada, despiram seus aventais de serviço. Não se retiraram do local de trabalho. Não houve qualquer prejuízo na produção. De modo que a suspensão é injusta. [...] seria forçoso reconhecer a injustiça do dispositivo regulamentar, porque as reclamantes, sendo mulheres, têm ocupações caseiras e domésticas que as trazem desejosas de deixar o serviço logo que o trabalho termine (Processo 337-339/51, fl. 10).

A parte reclamada em suas razões finais intimidou as operárias afirmando que se antes não prejudicaram a produção da empresa despindo-se antes da hora de saída, neste momento, prejudicavam saindo do serviço e convocando testemunhas: 
Embora conscientes da falta de razão, as reclamantes vem postular em Juízo, agora sim causando prejuízos à fábrica, com operários que saem do serviço como parte ou como testemunha, sem prejuízo de salário e com prejuízo da produção (Processo 337-339/51, fl. 11).

Este processo sintetizou a fala de todas as testemunhas já na conclusão do caso. Neste momento, foi possível notar que além das três operárias reclamantes, outras três foram suspensas tirando os aventais dois minutos antes da hora de sair e que isto deveria ser uma prática recorrente. Amparando-se no fato de que: "A reclamada [...] suspendeu as seis operárias, em virtude da quebra do princípio disciplinar, segundo a qual os trabalhadores só podem começar a se arrumar depois do apito " da fábrica" (Processo 337339/51, fl. 12) a Junta de Conciliação e Julgamento de Pelotas julgou improcedente a reclamatória das operárias.

Em 1948 a Cia. Fiação e Tecidos abriu um inquérito contra uma de suas operárias, Diva Jorge Moreira, a qual ingressou na fábrica em 2 de agosto de 1933, possuía portanto, estabilidade. Esta compareceu ao trabalho pela última vez em 29 de novembro de 1947. No dia $1^{\circ}$ de dezembro enviou um bilhete avisando que deixava de ir ao trabalho naquele dia por ter levado uma filha ao centro de saúde (Processo 125/48).

Segundo o representante da fábrica: "Depois desse aviso, nenhuma satisfação mais foi dada. É o caso típico, portanto, de abandono de emprego"

(Processo 125/48, fl. 2). A audiência foi marcada para o dia 4 de maio de 1948. Diva defendeu-se alegando que:

[...] de fato permaneceu afastada do serviço [...] que isso ocorreu porque [...] é abandonada pelo esposo, necessitando trabalhar para manter vários filhos; que sua ausência foi justificada, em parte, pelas circunstâncias mencionadas e porque necessitou ficar no lar tratando de suas filhas doentes; que, ao voltar ao trabalho, foi informada do processo; que espera que o processo seja julgado improcedente e que, se procedente, espera que ao menos a reclamante lhe volte a dar serviço, indispensável a sua subsistência, celebrando novo contrato de trabalho, de todo independente do que a empresa quer agora rescindir (Processo 125/48, fl. 6).

Diva, entre todas as operárias pesquisadas, foi a que depôs de forma mais autônoma, sendo menos "mediada" por seu advogado. Neste processo ela apropriou-se da 
ideologia da domesticidade apresentando-se como uma mulher abandona destrado em História da UFRN e que necessitava manter-se a si mesma e a vários filhos. Justificou sua ausência porque tinha de tratar suas filhas doentes. Diva configurou-se não somente na imagem da "mãesacrifício", mas também da "mulher-sacrifício", abandonada pelo marido.

Notou-se na fala da operária Diva, na defesa dos advogados das trabalhadoras e na conclusão dos Juízes do Tribunal Regional da $4^{a}$ região o que o historiador Benito Schmidt (2013) denomina de "táticas de gênero". Silvia Petersen (1994) explicou o que é uma tática e como ela ocorre:

A tática é a natureza da lógica cotidiana. As táticas não possuem espaço autônomo, realizam-se no espaço do outro, onde se insinuam fragmentadamente, sem ocupá-lo em sua totalidade e dependendo das circunstâncias fornecidas pelo espaço estranho sobre o qual atuam. Isto confere as táticas uma grande mobilidade, mas uma mobilidade que precisa aceitar a chance oferecida pelo momento e tomar para si as possibilidades que se the oferecem em uma circunstância dada. Ela abre seus espaços, pode estar onde menos se espera, cria surpresas, é uma artimanha astuciosa" (PETERSEN, 1994, p. 119).

Schmidt (2013), apropriando-se da diferenciação estabelecida por Michel de Certeau entre os conceitos de estratégia e tática, observou que "o fraco" pode agregar imagens ao seu discurso, tanto quanto "o forte". O autor, através de um litígio sobre uma sapateira, analisou como esta se apropriou das imagens de gênero de forma tática: foi acusada de "insubordinada" e defendeu-se como "mãe extremosa", justificando suas ausências no trabalho com o cuidado aos filhos.

Estamos nos valendo aqui da diferenciação feita por Michel de Certeau entre estratégias e táticas. De acordo com o historiador, as primeiras são as formas pelas quais os "proprietários do poder" exercem a sua dominação e são estabelecidas a partir de um lugar próprio que lhes serve de base à gestão de suas relações com a exterioridade. Já as táticas correspondem às formas sutis de resistência dos fracos; elas não tem lugar próprio e agem astuciosamente no espaço do outro, apropriando-se de forma criativa e por vezes subversiva dos produtos impostos pelas elites" (SCHMIDT, 2013, p. 195).

Edward Thompson (1987) defendeu que a lei media e legitima as relações de classes existentes, porém, algumas vezes a forma que a retórica dessa lei é empregada pode oferecer alguma proteção aos destituídos de poder. Referindo-se ao século XX e diferenciando o poder arbitrário do domínio da lei, afirmou: 
O domínio da lei em si, a imposição de restrições efetivas ao poder e a defesa do cidadão frente às pretensões de total intromissão do poder parecem-me um bem humano incondicional. Negar ou minimizar esse bem, neste século perigoso em que continuam a se ampliar os recursos e as pretensões do poder, é um erro temerário de abstração intelectual (THOMPSON, 1987, p. 357).

Daniel James, pesquisando sobre sindicalismo peronista, entrevistou a primeira operária líder sindical do Frigorífico Swift em Berisso, na província de Buenos Aires, "Doña María", também esposa, mãe e dona de casa. O dilema da dupla jornada está presente em toda a narrativa oral de Dona Maria, na qual ela tencionou os valores "a militante" e "a boa mãe-esposa”, apresentada por James. Segundo ele:

Defrontada com a realidade do status e do poder desiguais das mulheres em uma sociedade com relações de gênero profundamente hierárquicas, a adoção e a valorização de elementos de uma ideologia de maternidade e domesticidade podem muito bem ser vistas como uma opção racional (JAMES, 2004, p. 310).

Concluiu-se que esta apropriação da "ideologia da domesticidade" (SCOTT, 1992a) utilizada como tática, através da análise dos dissídios nem sempre deu certo. No caso de Diva, por exemplo, a Junta de Conciliação e Julgamento de Pelotas considerou que ela afastou-se sem justificar o motivo, caracterizando abandono de emprego e julgou procedente o inquérito, autorizando a despedida da "mãe-operária". Todavia, a tática utilizada pelos "fracos", operária e seu advogado, pode alcançar um grau de convencimento chegando a ser aceita e apropriada unanimemente por vários juízes de um tribunal regional, conforme o processo trabalhista $96 / 44$ da $4^{\text {a }}$ região.

\section{O ARREMATE}

No banco de dados do Núcleo de Documentação Histórica da UFPel as mulheres representam apenas 15\% das demandas. Já na Companhia Fiação e Tecidos Pelotense, que tinha a maioria de sua mão de obra composta por mulheres, elas representam cerca de $70 \%$ entre os demandantes. Porém, poucas vezes foi possível "ouvir" suas vozes, não somente porque os autos são transcritos pelo escrivão, mas porque raramente elas eram chamadas a falar, seja na condição de reclamantes ou como testemunhas, sendo dada prioridade de fala ao seu advogado. Entretanto, foi possível encontrar os anseios de algumas destas mulheres através das fontes. 
Nair Pereira de Freitas, a operária citada na introdução dést Mestrado em Historín dis dunters anseios, perceptíveis através da fonte: poder cuidar de seus filhos doentes, não ter sido demitida, ter condições financeiras para contratar uma babá ou que a Cia. Fiação e Tecidos tivesse uma creche onde ela pudesse deixar seus filhos durante sua jornada fabril.

Em relação à menção de Nair sobre a ausência de creches na empresa, o advogado desta, apropriando da ideologia da domesticidade, no momento em que defendeu que os filhos deveriam permanecer no lar, alegou:

\footnotetext{
Pouco importa, também, que a requerente não possua creche, como se vê nas fls. 7. Nenhuma empresa, no Brasil, está a isso obrigada por lei. Pelo contrário, nosso legislador não é propugnador da instituição de creches no local de trabalho, pelo motivo muito simples de que isso exigiria constantes, longas e penosas remoções dos filhos da mulher operária do lar para o lugar de prestação de serviços e vice-versa. Tanto assim que, como determina o art. 397, o encargo de criar e manter creches cabe às instituições de previdência social, nas vilas operárias de mais de cem casas e nos centros residenciais (Processo 172/48, fl. 8).
}

A fábrica permaneceu acusando-a de ter faltado muitos meses ao trabalho e que a doença dos filhos não seria motivo justo, pois não a impediria de exercer sua função, deste modo, não deveria perceber os salários. A reclamatória de Nair foi julgada improcedente e esta além de perder o emprego não ganhou os salários reclamados.

As operárias citadas neste artigo apropriaram-se da imagem de "mãesacrifício" ou "boa esposa", construídas socialmente e amparadas na ideologia da domesticidade, na maioria das vezes com auxílio do seu advogado, para utilizá-la como "tática de gênero". Assim, através da apropriação da condição de "mulheres sacrifícios" conseguiram justificar suas ausências no trabalho perante a Junta de Conciliação e Julgamento de Pelotas e no caso do processo 96/44 sensibilizaram os Juízes do Tribunal Regional do Trabalho da $4^{a}$ Região que firmaram uma sentença favorável, chegando a considerá-las de "[...] uma grandeza d"ealma aos maiores sacrifícios disposta[s]" (Processo 96/44, fl. 54).

Embora, falassem pouco durante as audiências a astúcia destas mulheres é algo a se supor, não somente quando se apropriaram do discurso da domesticidade, embora mediadas pelo seu procurador legal, mas também quando elas - mulheres que enfrentaram falatórios a seu respeito em decorrência dos "perigos morais" que o trabalho fora de casa 


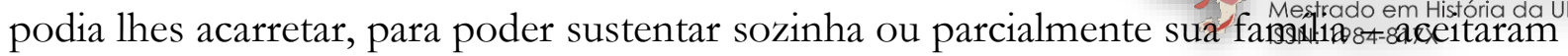
de forma naturalizada e interiorizada ou não, ser subjugadas a tal discurso, no intuito de tentar ganhar sua causa judicial.

Talvez as operárias apresentadas nesta pesquisa não tenham participado de greves, não tenham subido em palanques a discursar, não tenham militado pela causa feminista e da classe trabalhadora e não tenham integrado nenhum tipo de liderança nos seus espaços de sociabilidade, como Patrícia Galvão (Pagu) e as operárias do seu romance Parque Industrial (1933). Porém, o que não se pode negar a coragem que tiveram de enfrentar um tribunal composto somente por homens, para reivindicar causas consideradas culturalmente suas como a licença e o salário maternidade, de forma explícita e o direito de não necessitar optar entre trabalhar na fábrica ou cuidar do lar e dos filhos, de modo implícito.

\section{FONTES:}

Acervo da Justiça do Trabalho/NDH-UFPel. Processo 172/48. Reclamante: Nair Pereira de Freitas. Lote 31.

Acervo da Justiça do Trabalho/NDH-UFPel. Processo 200/48. Reclamante: Companhia Fiação e Tecidos Pelotense. Lote 30.

Acervo da Justiça do Trabalho/NDH-UFPel. Processo 96/44. Reclamante: Branca Pradier Oliveira. Lote 12.

Acervo da Justiça do Trabalho/NDH-UFPel. Processo 337-339/51.

Reclamantes: Sara Gronês, Rita Jesus Pereira e Carmem Alberto. Lote 51.

Acervo da Justiça do Trabalho/NDH-UFPel. Processo 125/48.

Reclamante: Companhia Fiação e Tecidos Pelotense. Lote 27.

Decreto-lei 5.452 de 1943. Consolidação das Leis do Trabalho.

Disponível em: http://www.planalto.gov.br/ccivil 03/decreto-

lei/del5452.htm. Acesso em: 24/01/2014.

RUSSOMANO, Mozart Victor. Da proteção do trabalho da mulher. In:

Comentários à Consolidação das Leis do Trabalho. Vol. II, $5^{a}$ Ed., Rio de Janeiro: José Konfino (editor), 1960. p. 554-584.

\section{REFERÊNCIAS BIBLIOGRÁFICAS:}

BIAVASCHI, Magda. O Direito do Trabalho no Brasil - 1930-1942: A construção do sujeito de direitos trabalhistas. Tese de Doutorado, Economia, Campinas, 2005.

CHALHOUB, Sidney. Trabalho, lar e botequim: o cotidiano dos trabalhadores no Rio de Janeiro da belle époque. - $2^{\mathrm{a}}$ Ed. - Campinas: Editora da UNICAMP, 2001.

DEL PRIORE, Mary. Histórias do cotidiano. São Paulo: Contexto, 2008.

ESSINGER, Cíntia Vieira. Entre a fábrica e a rua: a Companhia Fiação e Tecidos Pelotense e a criação de um espaço operário, Bairro da Várzea, Pelotas, RS (1953 -1974). Dissertação de Mestrado, Memória Social e Patrimônio Cultural, Universidade Federal de 
Pelotas, 2009.

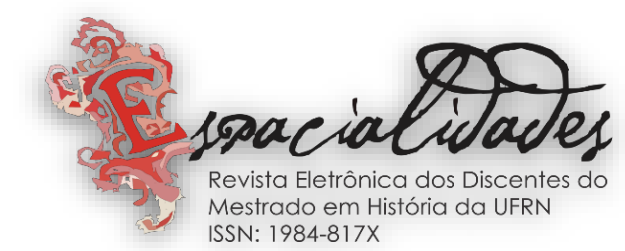

GALVÃO, Patrícia. Parque industrial. Rio de Janeiro: José Olympio, 2006.

GOMES, Ângela de Castro. Questão social e historiografia no Brasil do pós-1980: notas para um debate. Estudos Históricos, Rio de Janeiro, no 34, p. 157-186, 2004.

JAMES, Daniel Contos narrados nas fronteiras: a história de Doña María, história oral e questões de gênero. In: BATALHA, Claudio; SILVA, Fernando Teixeira da; FORTES, Alexandre. (Orgs.) Cultura de classe: identidade e diversidade na formação do operariado. Campinas: Editora da UNICAMP, 2004. p. 287-314.

KARAWEJCZYK, Mônica. Breves considerações sobre a conquista do voto feminino no Brasil. Veredas da História. Ano 3, ed. 1, p. 1-23, 2010.

LORNER, Beatriz Ana. Construção de classe: operários de Pelotas e Rio Grande (18881930). Pelotas: Unitrabalho, 2001.

LOPES, Cristiane. Direito do trabalho da mulher: da proteção à promoção. Cadernos Pagu (26), p. 405-430, 2006.

PERROT, Michelle. Minha história das mulheres. São Paulo: Contexto, 2008.

. Os excluídos da história: Operários, mulheres e prisioneiros. Rio de Janeiro: Paz e Terra, 1988.

PETERSEN, Silvia Regina Ferraz. A renovação da historiografia e o tema da vida cotidiana: desfazendo alguns equívocos. In: Claudia Mauch... [et. al.]. Porto Alegre na virada do século 19: cultura e sociedade. Porto Alegre/Canoas/São Leopoldo: Ed. Universidade/UFRGS/Ed. ULBRA/Ed. UNISINOS, 1994. p. 112-125.

RAGO, Margareth. Trabalho feminino e sexualidade. In: DEL PRIORE, Mary. História das mulheres no Brasil. São Paulo: Contexto/UNESP, 1997. p. 578-606.

. Do cabaré ao lar: a utopia da cidade disciplinar, Brasil 1980-1930. Rio de Janeiro: Paz e Terra, 1985.

SCHMIDT, Benito Bisso. Práticas e táticas: Michel de Certeau (re) inventa o cotidiano. Biblos, Rio Grande, v. 6, p.79-93, 1994.

A sapateira insubordinada e a mãe extremosa: disciplina fabril, táticas de gênero e luta por direitos em um processo trabalhista (Novo Hamburgo, RS, 1958-1961). In: GOMES, Ângela de Castro; SILVA, Fernando Teixeira da (Org.). A Justiça do Trabalho e sua história: os direitos dos trabalhadores no Brasil. Campinas, SP: Editora da Unicamp, 2013. p. 157-202.

SCOTT, Joan. A mulher trabalhadora. In: DUBY, George; PERROT, Michelle. História das mulheres: o século XIX. Porto: Edições Afrontamento, 1992a. p. 444-474.

. Gênero: uma categoria útil para análise histórica. Educação \& Realidade. Porto Alegre, vol. 20, no 2, p. 71-99, 1995.

. História das mulheres. In: BURKE, Peter (Org.). A escrita da história: novas perspectivas. São Paulo: Editora da Universidade Estadual Paulista, 1992b. p. 63-95.

SOIHET, Rachel; PEDRO, Joana Maria. A emergência da pesquisa da História das Mulheres e das Relações de Gênero. Revista Brasileira de História. São Paulo, v. 27, $\mathrm{n}^{\circ}$ 54, p. 281-300, 2007.

SPERANZA, Clarice Gontarski. Cavando Direitos: as leis trabalhistas e os conflitos entre trabalhadores e patrões nas minas do Rio Grande do Sul nos anos 40 e 50 . Tese (doutorado) - Programa de Pós-Graduação em História do Instituto de Filosofia e Ciências Humanas da UFRGS. Porto Alegre, 2012.

THOMPSON, Edward. Senhores e caçadores: a origem da lei negra. Rio de Janeiro: Paz e Terra, 1987. 